\title{
PENGGUNAAN WARNA LAMPU BAWAH AIR YANG BERBEDA PADA BUBU LIPAT MODIFIKASI SATU PINTU TERHADAP HASIL TANGKAPAN RAJUNGAN (Portunus spp)
}

\section{Usage of Different Colour Underwater Lamps on One-Funnel Modified Collapsible Pots for Blue Swimming Crabs (Portunus Spp)}

Oleh:

\author{
Khairil Ibaad ${ }^{1}$, Zulkarnain ${ }^{1 *}$, Sulaeman Martasuganda ${ }^{1}$, Tri Nanda Citra Bangun ${ }^{1}$ \\ ${ }^{1}$ Departemen Pemanfaatan Sumberdaya Perikanan, FPIK- \\ IPB, Bogor \\ *Korespondensi penulis: zulkarnain@apps.ipb.ac.id
}

\begin{abstract}
ABSTRAK
Bubu merupakan alat tangkap yang umum dikenal nelayan sebagai alat tangkap yang biasa dioperasikan pada dasar perairan menggunakan sistem rawai serta memiliki karakteristik pasif, selektif, dan ramah lingkungan. Lampu bawah air untuk alat tangkap bubu belum pernah dipraktekkan oleh nelayan khususnya pada pengoperasian bubu lipat rajungan. Penelitian ini bertujuan menentukan komposisi hasil tangkapan dan pengaruh penggunaan lampu bawah air yang berbeda pada bubu lipat penelitian terhadap hasil tangkapan serta menghitung produktivitas bubu lipat penelitian terhadap hasil tangkapan dan persentase kelayakan hasil tangkapan bubu lipat penelitian. Metode yang digunakan pada penelitian ini adalah experimental fishing dengan total bubu yang digunakan adalah 30 buah (masing-masing 10 unit bubu setiap perlakuan) dan dilakukan sebanyak 20 kali ulangan (trip). Metode analisis data yang digunakan adalah analisis deskriptif, uji normalitas, uji T dan uji Wilcoxon. Komposisi hasil tangkapan yang diperoleh pada bubu kontrol (bubu nelayan) 9 jenis dengan total 248 ekor seberat 23,39 kg, bubu modifikasi lampu putih mendapatkan 10 jenis dengan total 224 ekor seberat $25,94 \mathrm{~kg}$, bubu modifikasi lampu biru juga mendapatkan 10 jenis hasil tangkapan dengan total 167 ekor seberat 17,42 kg. Penggunaan lampu LED berwarna putih dinyatakan berpengaruh nyata dalam hasil tangkapan bernilai ekonomis baik dilihat dari jumlah (ekor) dan berat $(\mathrm{kg})$ apabila dibandingkan dengan bubu kontrol dan bubu modifikasi lampu biru.
\end{abstract}

Kata kunci: bubu lipat, lampu LED, rajungan, warna lampu

\section{ABSTRACT}

Traps are simple fishing gear well known by the fishermen. Trapping is passive way to catch fish, more selective to certain target species and more friendly to the environment. Using underwater lamps in collapsible crab pots is not commonly practiced among the fishermen. The purpose of this study are to calculate catch composition and to determine the impact of using underwater LED lamps on different pots to the catch also to measure productivity change of the pots to the catch and to measure the fishing capacity of each occupied pots. Data collection method used is experimental fishing technique. As many as 10 collapsible pots per variable are used in this experiment making 30 pots in total which are operated in 20 fishing trips. Data analysis methods used are descriptive analysis, normality test, T- test, and Wilcoxon test. Catch composition using commercial collapsible crab pots (controlled variable) are in total of 9 species consisting of 248 fish as much as $23,39 \mathrm{~kg}, 10$ species consisting of 224 fish as much as $25,94 \mathrm{~kg}$ in modified one-funnel with white LED lamps collapsible crab pots, and 10 species consisting of 167 fish as much as 17,42 $\mathrm{kg}$ in modified one-funnel with blue LED lamps collapsible crab pots. The usage of white LED lamps shows a significant result in commercially important fish caught either in amount or in weight comparing to the commercial 
collapsible crab pots (controlled variable) and modified one-funnel with blue LED lamps collapsible crab pots.

Key words: blue swimming crab, collapsible crab pots, LED lamps, lights color

\section{PENDAHULUAN}

Bubu merupakan alat tangkap yang umum dikenal dikalangan nelayan sebagai alat tangkap yang biasa dioperasikan pada dasar perairan menggunakan sistem rawai serta memiliki karakteristik pasif, selektif, dan ramah lingkungan. Secara umum bubu memiliki konstruksi yaitu badan bubu, mulut bubu, dinding bubu, tempat umpan, pemberat, tali-temali, pelampung, dan pelampung tanda. Lampu bawah air untuk alat tangkap bubu belum pernah dipraktekkan oleh nelayan khususnya pada pengoperasian bubu lipat rajungan. Sedangkan menurut teori, pemasangan lampu bawah air di dalam bubu akan menyebabkan ikan-ikan yang bersifat fototaksis positif akan tertarik pada cahaya dan berkumpul di sekitar area bubu. Penggunaan umpan di dalam bubu akan mempermudah dan mempercepat ikan target memasuki bubu lalu terperangkap.

Rajungan (Portunus pelagicus) merupakan salah satu sumberdaya perikanan yang bernilai ekonomis penting, karena sebagai komoditi ekspor. Permintaan rajungan yang tinggi dan harus kontinu mendorong sektor penangkapan rajungan untuk terus memenuhi kebutuhan rajungan sebagai produk segar dan olahan (Adam et al. 2006). Rajungan ditangkap oleh nelayan kebanyakan menggunakan bubu lipat, yaitu bubu yang terbuat dari bingkai besi galvanis dan badan bubu menggunakan jaring (cover net). Penangkapan rajungan menggunakan umpan asli yaitu ikan rucah. Pengembangan kontruksi bubu lipat rajungan telah dilakukan dari hasil penelitian Zulkarnain (2012) yaitu bubu lipat modifikasi satu pintu. Modifikasi yang telah dilakukan pada bubu lipat adalah memiliki satu pintu masuk, ukurannya dua kali lebih besar dibandingkan dengan bubu lipat rajungan nelayan dan menggunakan pintu yang berukuran besar yang terbuat dari plastik fiber.

Penggunaan alat bantu penangkapan berupa input teknologi pada bidang perikanan tangkap merupakan salah satu faktor yang mempengaruhi perkembangan perekonomian nelayan melalui peningkatan hasil tangkapan, peningkatan efektivitas alat tangkap, dan memastikan kualitas hasil tangkapan terjaga dengan baik. Salah satu contoh penggunaan alat bantu penangkapan tersebut adalah penggunaan cahaya lampu. Menurut Thahir dan Taufiq (2019) pemasangan lampu bawah air pada bubu memberikan pikatan cahaya kepada ikan-ikan berasosiasi positif dan berkumpul di sekitar bubu, sehingga akan memudahkan ikan akan masuk ke dalam bubu dan tertangkap. Teknologi lampu LED (light emitting diode) memiliki energi yang kecil namun memancarkan cahaya yang lebih terang. Menurut Yudha (2005), penggunaan light attractor berkedip pada dasarnya hanyalah meniru atau menyerupai kondisi sesungguhnya di alam karena ada jenis-jenis ikan tertentu yang bisa mengeluarkan cahaya sendiri untuk berkomunikasi atau untuk mencari makan. Yami (1976) dalam Yudha (2005) mengemukakan bahwa respon dan tingkah laku ikan terhadap cahaya buatan belum dipahami dengan baik untuk membandingkan, menjelaskan, ataupun memprediksi pola tingkah laku ikan untuk semua jenis.

Penggunaan lampu LED pada penelitian ini menduga bahwa adanya proses pengumpulan biota dasar laut ke arah sumber cahaya pada bubu tersebut serta memudahkan biota laut masuk ke dalam bubu. Harapan penggunaan lampu LED dapat meningkatkan hasil tangkapan dan ukuran rajungan yang tertangkap adalah ukuran-ukuran di atas length of maturity. Lampu LED yang digunakan pada penelitian kali ini berwarna cahaya biru dan putih dengan alasan cahaya biru memiliki frekuensi terbesar tetapi panjang gelombang terpendek yaitu sebesar $458 \mathrm{~nm}$ (Novita et al. 2019) sedangkan warna putih diperkuat oleh penelitian Yudha (2005) bahwa lampu putih adalah warna cahaya yang efektif untuk menangkap ikan karang. Penggunaan lampu bawah air ini diharapkan juga mampu 
mendapatkan hasil tangkapan yang lebih baik dari segi ukuran dan jumlah ikan serta rajungan yang tertangkap.

Berdasarkan uraian di atas, permasalahan dalam penelitian ini adalah input teknologi belum pernah dilakukan nelayan bubu terhadap alat tangkapnya sehingga efektifitas penangkapan cenderung stagnan dan belum dipahami dengan baik respon serta tingkah laku ikan karang terhadap cahaya buatan yang dalam hal ini yaitu lampu LED, penggunaan lampu LED pada bubu diharapkan dapat meningkatkan hasil tangkapan rajungan (Portunus sp).

Tujuan penelitian ini adalah membandingkan komposisi hasil tangkapan pada bubu lipat penelitian, menentukan pengaruh penggunaan lampu bawah air yang berbeda pada bubu lipat penelitian terhadap hasil tangkapan, menentukan produktivitas bubu lipat penelitian terhadap hasil tangkapan, dan menentukan presentase kelayakan hasil tangkapan rajungan dan jenis lainnya pada bubu lipat penelitian.

\section{METODE PENELITIAN}

Kegiatan penelitian pendahuluan dengan merancang bangun bubu modifikasi di Laboratorium Teknologi Penangkapan Ikan, Departemen Pemanfaatan Sumberdaya Perikanan, Fakultas Perikanan dan Ilmu Kelautan IPB pada bulan Januari 2020. Kemudian uji coba alat pada bulan Februari 2020 di Pemalang, Provinsi Jawa Tengah. (Gambar 1).

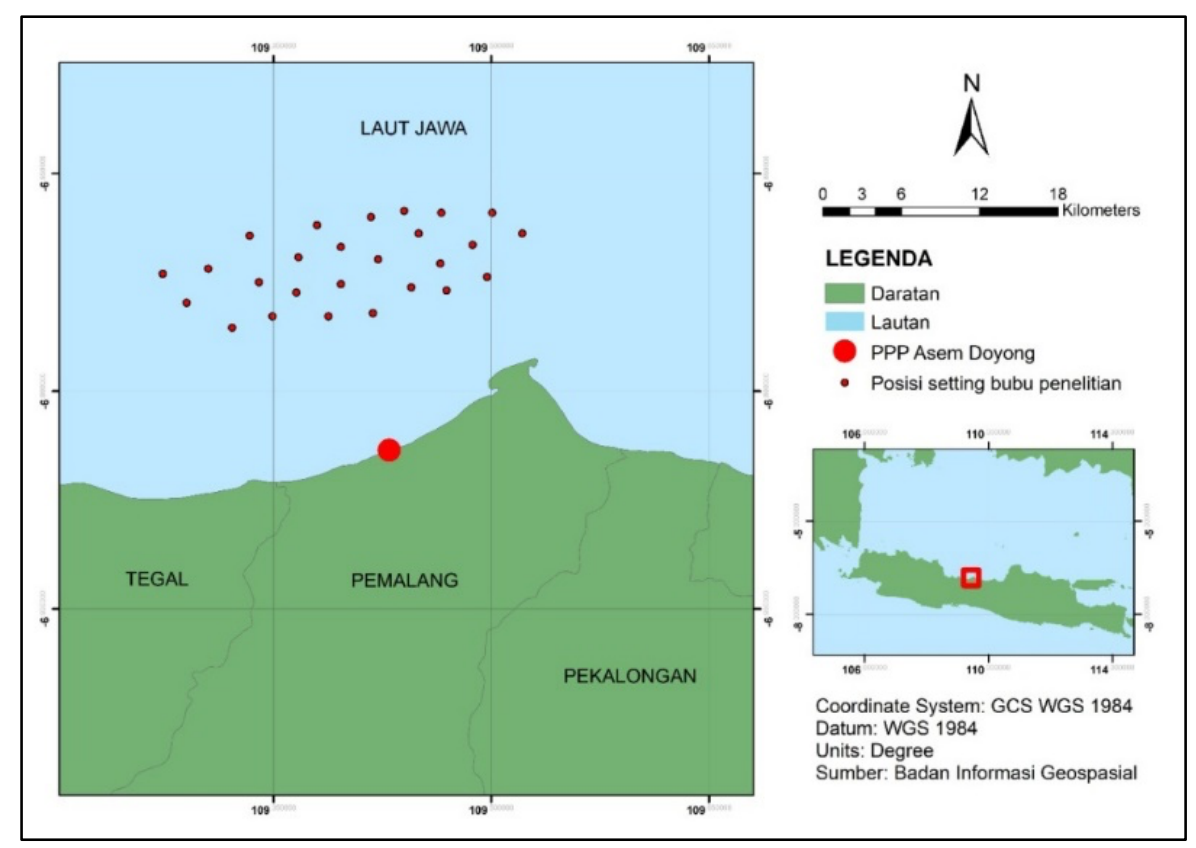

Gambar 1 Peta lokasi penelitian

Data alat dan bahan penelitian yang digunakan dalam kegiatan desain bubu lipat modifikasi terdiri dari perangkat komputer yang terhubung dengan sistem internet yang digunakan untuk mendapatkan informasi jurnal sebagai referensi konstruksi desain bubu, alat tulis, kamera digital untuk dokumentasi proses pada saat setting, hauling, dan hasil tangkapan. Alat dan bahan penelitian dalam kegiatan adalah lampu LED rakitan pabrik, pembuatan bubu lipat modifikasi terdiri dari besi galvanis, jaring, benang, tali, dan coban plastik. Sedangkan alat dan bahan yang digunakan dalam skala penelitian antara lain perahu jukung 20 trip, unit alat tangkap bubu sistem longline, timbangan, termometer, kantong plastik bening, dan spidol permanen. 
Tabel 1 Spesifikasi bubu lipat modifikasi satu pintu

\begin{tabular}{ll}
\hline \multicolumn{1}{c}{ Alat } & \multicolumn{1}{c}{ Spesifikasi } \\
\hline Nama & Bubu lipat modifikasi satu pintu \\
Bentuk Bubu & Persegi panjang \\
Ukuran Bubu & $60 \mathrm{~cm}$ x $45 \mathrm{~cm}$ x $30 \mathrm{~cm}$ ( p x l x t ) \\
Jumlah Pintu masuk & 1 pintu, pintu samping \\
Jenis Modifikasi & Ukuran bubu lebih besar dibanding bubu yang dioperasikan nelayan \\
& Ukuran pintu masuk cukup lebar \\
& Slopet net atas dan bawah: 22,5 \\
& Terdapat modifikasi berupa kisi-kisi pada pintu masuk bubu yang \\
& berguna agar hasil tangkapan sulit lolos \\
& Ruang dalam bubu lebih besar \\
Bingkai & Besi galvanis, diameter 6 mm \\
Badan Jaring & PE mesh size 1,5 inch, 210 D/18 \\
\hline
\end{tabular}

Sumber: Zulkarnain 2012

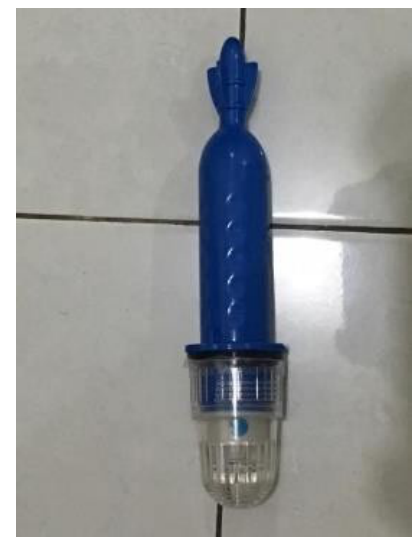

a

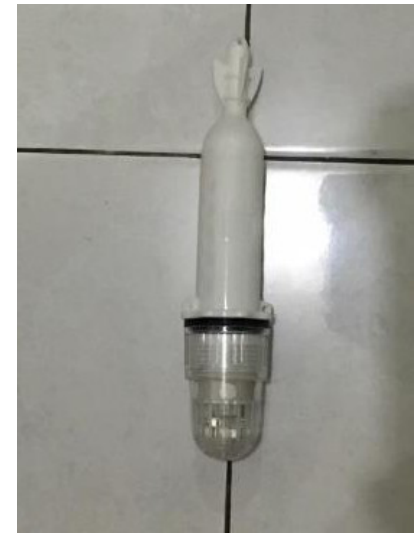

b

Gambar 2 Lampu LED bawah air biru (a) dan putih (b)

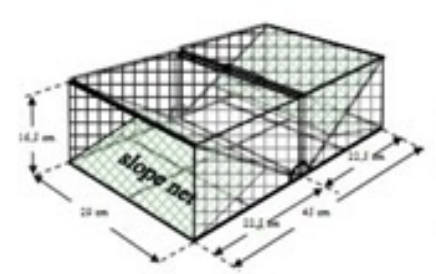

a

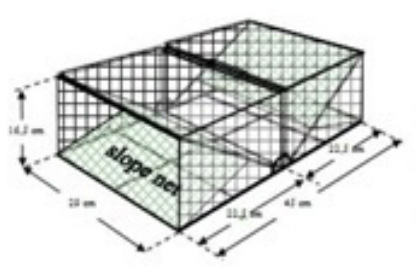

B

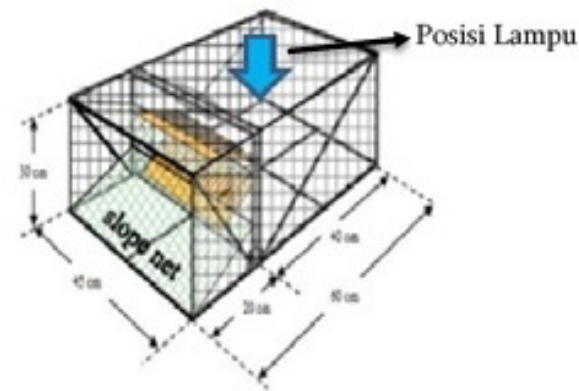

C

Gambar 3 (a) Bubu lipat kontrol; (b) bubu lipat modifikasi satu pintu; (c) posisi lampu di dalam bubu

Metode yang digunakan dalam penelitian ini adalah metode experimental fishing. Tujuan dari penelitian eksperimental adalah untuk menyelidiki ada tidaknya suatu hubungan sebab akibat serta berapa besar hubungan sebab akibat tersebut dengan cara melakukan perlakuan-perlakuan tertentu pada beberapa kelompok eksperimental dan menyediakan kontrol untuk perbandingan (Nazir 2003). 


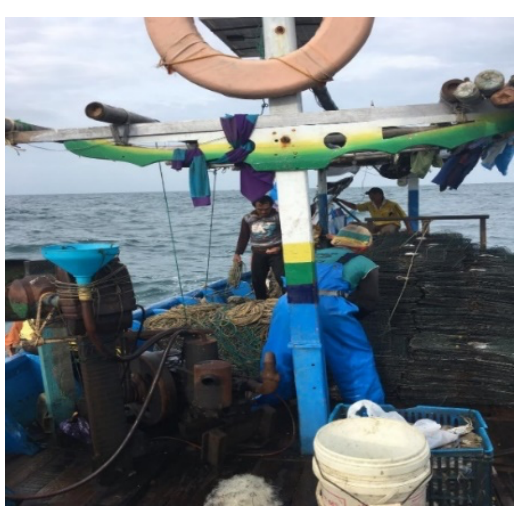

a

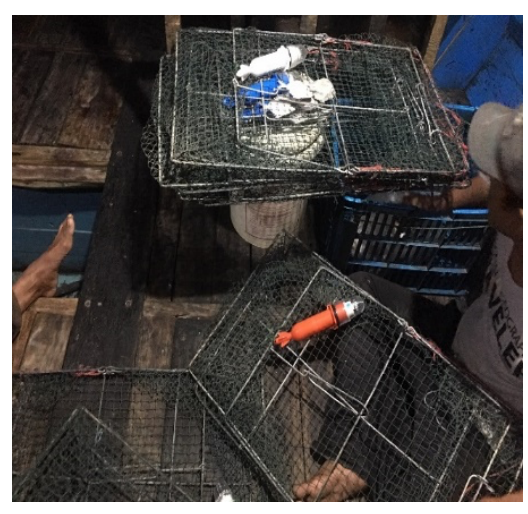

$\mathrm{b}$

Gambar 4 (a) Kegiatan setting bubu; (b) penempatan lampu pada bubu penelitian

Pengukuran intensitas cahaya dilakukan menggunakan lux meter. Prosedur penggunaan lux meter yaitu dengan cara mengarahkan sensor lux meter kepada cahaya lampu kemudian melihat angka yang tertera pada layar lux meter. Pengukuran intensitas cahaya dilakukan pada 2 media yaitu udara dan air laut. Pengukuran pada media udara melalui sudut dan jarak, sedangkan pada media air laut berdasarkan pertemuan titik jarak vertikal dan horizontal $10-50 \mathrm{~cm}$.

Berdasarkan metode penelitian maka data yang diperoleh adalah perbandingan hasil tangkapan rajungan dan jenis lainnya antara bubu lipat modifikasi satu pintu yang diberi lampu (bubu percobaan) dengan bubu kontrol milik nelayan. Data diperoleh dari dari sepuluh bubu lipat modifikasi satu pintu yang diberi lampu (bubu percobaan) dan bubu kontrol milik nelayan yang dioperasikan di Perairan Asemdoyong, Pemalang, Jawa Tengah. Bubu percobaan dan bubu kontrol di-setting pada pagi hari pukul 07.00 dan didiamkan selama kurang lebih 24 jam, lalu akan dilakukan hauling pada pukul 04.00 keesokan hari nya. Data yang diolah merupakan data primer. Data primer yang diambil adalah lokasi fishing ground, waktu hauling, waktu setting, jenis ikan yang tertangkap, jumlah ikan yang tertangkap, berat ikan, pengukuran karapas pada jenis ikan berkarapas.

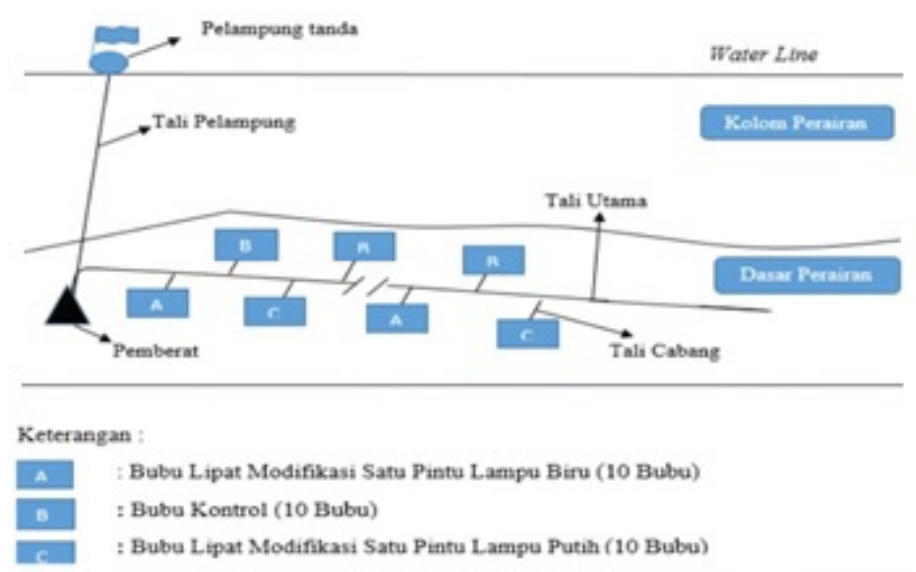

Gambar 5 Urutan penyusunan bubu lipat penelitian dalam experimental fishing

Analisis deskriptif bertujuan untuk mengubah sekumpulan data mentah menjadi bentuk yang lebih mudah dipahami yang berbentuk informasi yang lebih ringkas (Ashari et al. 2017). Uji Normalitas berguna untuk menentukan data yang telah dikumpulkan berdistribusi normal atau diambil dari populasi normal. Hasil tangkapan akan dikelompokan dalam selang kelas panjang karapas ( $\mathrm{mm}$ ) dan selang berat (gram) yang dihitung dengan rumus : LEBAR KELAS (i) = (nilai terbesar-nilai terkecil): $\mathrm{K}$, diketahui $K=1+3,3 \log n$. 
Uji normalitas yang digunakan uji One Sample Kolmogorov-Smirnoff dengan menggunakan program IBM SPSS statistics 25. Data dapat dikatakan berdistribusi normal apabila nilai signifikansi (Sig) $>$ 0,05 dan jika nilai signifikansi (Sig) < 0,05 maka distribusi data tidak normal (Santoso 2001). Selanjutnya data diolah dengan menggunakan uji lanjut berupa uji T. Uji T (Independent sample t-test) dilakukan apabila data menyebar normal. Uji T dilakukan untuk mengetahui pengaruh dari kedua sampel terhadap jumlah hasil tangkapan dengan menggunakan program IBM SPSS statistics 25 pada selang kepercayaan $95 \%(\alpha=0,05)$ dengan hipotesis: $\mathrm{HO}=$ Perbedaan alat tangkap tidak berpengaruh terhadap data hasil tangkapan, $\mathrm{H} 1$ = Perbedaan alat tangkap berpengaruh terhadap data hasil tangkapan. Adapun kaidah yang digunakan dalam pengambilan keputusan : Jika nilai signifikansi 2 Tailed > 0,05, maka H0 ditolak; Jika nilai signifikansi 2 -Tailed $<0,05$, maka H1 diterima. Sedangkan data yang tidak menyebar normal dilakukan uji lanjut dengan menggunakan uji non-parametrik berupa uji Wilcoxon. Dasar pengambilan keputusan uji Wilcoxon sebagai berikut: Jika nilai Asymp. Sig (2 Tailed) lebih kecil dari <0,05, maka H0 diterima. Sebaliknya, jika nilai Asymp. Sig (2 -Tailed) lebih besar dari $>0,05$, maka H0 ditolak, H1 diterima. Hipotesis pengambilan keputusan : H0 : Ada perbedaan antara bubu lipat nelayan (kontrol) dengan bubu lipat dan H1 : Tidak ada perbedaan antara bubu lipat nelayan (kontrol) dengan bubu.

Produktivitas bubu adalah jumlah hasil tangkapan per trip per bubu (kg/trip/bubu) pada setiap bubu lipat yang diuji. Adapun rumus produktivitas bubu sebagai berikut :

$$
\text { Produktivitas bubu }=\bar{R}_{R}+\bar{R}_{B E P}
$$

Keterangan:

$\overline{\mathrm{R}_{\mathrm{R}}} \quad=$ rata-rata hasil tangkapan rajungan bubu lipat

$\overline{\mathrm{R}_{\mathrm{BEP}}} \quad=$ rata-rata hasil tangkapan lainnya bernilai ekonomis tinggi

Nilai rata-rata hasil tangkapan rajungan pada bubu lipat diperoleh dengan menggunakan persamaan:

$$
\frac{\text { Total rajungan }}{\text { Total trip } x \text { total bubu }}
$$

Sedangkan nilai rata-rata hasil tangkapan lainnya bernilai ekonomis penting pada alat tangkap bubu lipat menggunakan persamaan :

$$
\frac{\text { Total HT lainnya ekonomis penting }}{\text { Total trip x total bubu }}
$$

\section{HASIL DAN PEMBAHASAN}

\section{Iluminasi Cahaya Lampu LED di Air Laut}

Cara pengukuran intensitas lampu LED saat di dalam air laut adalah dengan meletakan sensor lux meter pada titik pertemuan antara jarak horizontal dan jarak vertikal $(10-50 \mathrm{~cm})$, terhitung ada 25 titik. Pola penyebaran intensitas cahaya pada media air laut diolah melalui aplikasi Surfer. Adapun perbedaan cara mengolah pola sebaran intensitas cahaya dikarenakan ada perbedaan juga pada cara pengukuran. Pola penyebaran intensitas cahaya pada media air laut dapat dilihat pada Gambar 6. 


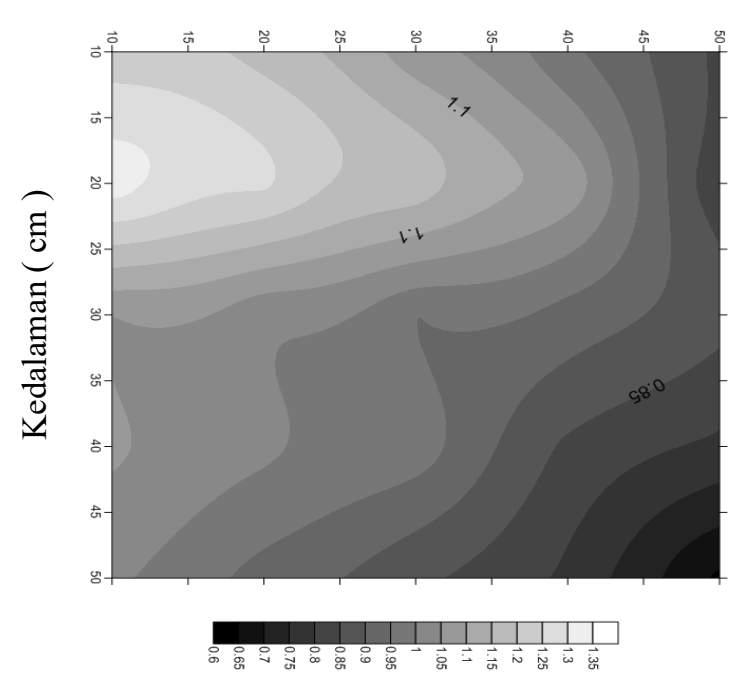

a

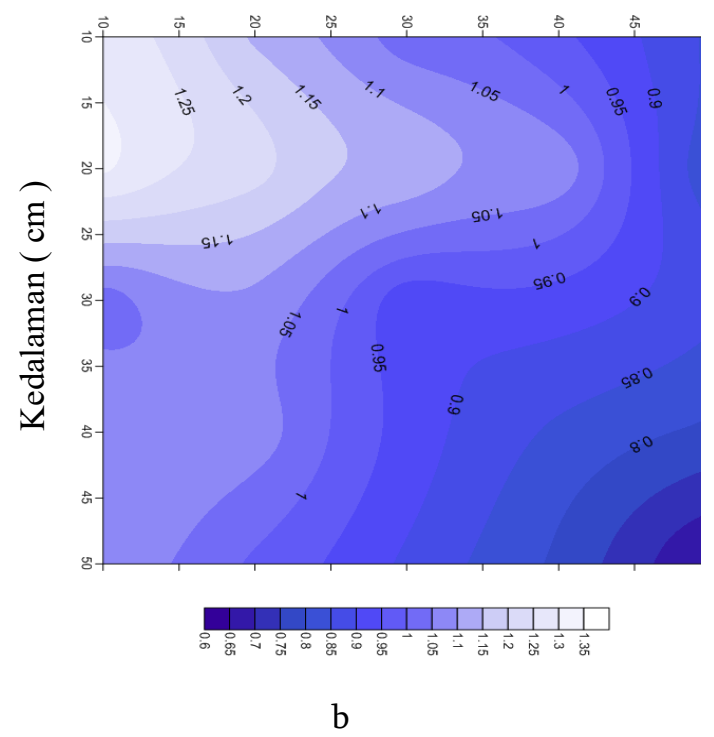

Gambar 6 (a) Pola pancaran lampu LED warna putih; (b) Pola pancaran lampu LED warna biru

\section{Komposisi Hasil Tangkapan}

Data hasil tangkapan diperoleh berdasarkan experimental fishing. Data dicatat dan dibagi berdasarkan berat $(\mathrm{kg})$ dan jumlah (ekor). Data tersebut dapat dlihat pada Tabel 2.

Tabel 2 Komposisi hasil tangkapan dalam jumlah (ekor)

\begin{tabular}{|c|c|c|c|c|c|c|c|c|c|}
\hline \multirow{3}{*}{ No. } & \multirow{3}{*}{ Nama Lokal } & \multirow{3}{*}{ Nama Inggris } & \multirow{3}{*}{ Nama Ilmiah } & \multicolumn{6}{|c|}{ Hasil Tangkapan } \\
\hline & & & & \multicolumn{2}{|c|}{$\begin{array}{l}\text { Bubu Lipat } \\
\text { Kontrol }\end{array}$} & \multicolumn{2}{|c|}{$\begin{array}{c}\text { Bubu Lipat } \\
\text { Modifikasi } \\
\text { Lampu putih }\end{array}$} & \multicolumn{2}{|c|}{$\begin{array}{l}\text { Bubu Lipat } \\
\text { Modifikasi } \\
\text { Lampu biru }\end{array}$} \\
\hline & & & & Ekor & $\begin{array}{l}\text { Berat } \\
(\mathrm{Kg})\end{array}$ & Ekor & $\begin{array}{l}\text { Berat } \\
(\mathrm{Kg})\end{array}$ & Ekor & $\begin{array}{l}\text { Berat } \\
(\mathrm{Kg})\end{array}$ \\
\hline \multirow[t]{2}{*}{1} & Rajungan & $\begin{array}{l}\text { Blue Swimming } \\
\text { Crab }\end{array}$ & $\begin{array}{l}\text { Portunus } \\
\text { pelagicus }\end{array}$ & 96 & 15,53 & 78 & 13,07 & 76 & 11,89 \\
\hline & Subtotal & & & 96 & 15,53 & 78 & 13,07 & 76 & 11,89 \\
\hline 2 & Kakap merah & Snapper fish & Lutjanus $s p$ & 5 & 0,81 & 18 & 4,1 & 3 & 1,12 \\
\hline 3 & Kuniran & Kuniran fish & $\begin{array}{l}\text { Upeneus } \\
\text { moluccensis }\end{array}$ & 2 & 0,2 & 9 & 1,7 & 2 & 0,84 \\
\hline 4 & Baronang & Rabbit fishes & Siganus sp & 0 & 0 & 13 & 1,2 & 4 & 0,42 \\
\hline 5 & Sotong & Cuttlefish & Sepia $s p$ & 2 & 0,19 & 13 & 1,3 & 3 & 0,82 \\
\hline 6 & Udang ronggeng & Squilla mantis & Harpiosquilla $s p$ & 14 & 0,46 & 9 & 1,1 & 5 & 0,47 \\
\hline 7 & Cumi-cumi & Squid & Loligo $s p$ & 0 & 0 & 8 & 1,6 & 3 & 0,62 \\
\hline 8 & Gerot- gerot & $\begin{array}{l}\text { Spotted } \\
\text { javelinfish }\end{array}$ & $\begin{array}{l}\text { Pomadasys } \\
\text { maculatus }\end{array}$ & 4 & 0,64 & 0 & 0 & 0 & 0 \\
\hline \multirow[t]{3}{*}{9} & Gurita & Octopus & Octopus sp & 3 & 0,52 & 11 & 1,18 & 2 & 0,56 \\
\hline & Subtotal & & & 30 & 2,30 & 81 & 11,3 & 22 & 4,29 \\
\hline & Total & & & 126 & 17,8 & 159 & 24,3 & 98 & 16,1 \\
\hline
\end{tabular}

Tabel 2 menunjukan hasil tangkapan keseluruhan dalam jumlah (ekor) dan berat (kg), secara keseluruhan rajungan merupakan hasil tangkapan utama yang bernilai ekonomis. Keseluruhan trip menunjukan bahwa bubu kontrol mendapatkan 96 ekor rajungan (15,53 kg), bubu modifikasi lampu putih 78 ekor rajungan $(13,07 \mathrm{~kg})$, bubu modifikasi lampu biru 76 ekor $(11,89 \mathrm{~kg})$. 


\section{Kelayakan Tangkapan Berdasarkan Length of Maturity}

Ukuran layak tangkap biasanya mengacu pada ukuran pertama kali matang gonad ikan tersebut. Sebaran data dapat dilihat pada Tabel 3.

Tabel 3 Sebaran hasil tangkapan berdasarkan layak dan tidak layak tangkap

\begin{tabular}{|c|c|c|}
\hline Jenis Bubu & Layak Tangkap & Tidak Layak Tangkap \\
\hline \multirow[t]{5}{*}{ Bubu Kontrol } & Rajungan 90\% & Rajungan $10 \%$ \\
\hline & Gurita 33\% & Kakap merah $100 \%$ \\
\hline & Udang ronggeng 86\% & Gurita $67 \%$ \\
\hline & Kuniran 100\% & Udang ronggeng $14 \%$ \\
\hline & & Sotong $100 \%$ \\
\hline \multirow[t]{4}{*}{ Bubu Lampu Putih } & Rajungan 74\% & Rajungan 26\% \\
\hline & Gurita $18 \%$ & Kakap merah $100 \%$ \\
\hline & Udang ronggeng 56\% & Baronang 100\% \\
\hline & Cumi-cumi 38\% & Gurita $82 \%$ \\
\hline \multirow[t]{4}{*}{ Bubu Lampu putih } & Kuniran 22\% & Udang ronggeng 44\% \\
\hline & & Cumi-cumi $62 \%$ \\
\hline & & Sotong $100 \%$ \\
\hline & & Kuniran 78\% \\
\hline \multirow[t]{8}{*}{ Bubu Lampu Biru } & Rajungan 71\% & Rajungan 29\% \\
\hline & Udang ronggeng 20\% & Kakap merah $100 \%$ \\
\hline & Cumi-cumi 33\% & Baronang $100 \%$ \\
\hline & & Gurita $100 \%$ \\
\hline & & Udang ronggeng 80\% \\
\hline & & Cumi-cumi $67 \%$ \\
\hline & & Sotong 100\% \\
\hline & & Kuniran $100 \%$ \\
\hline
\end{tabular}

\section{Pengujian Statistik}

Hasil output uji $\mathrm{T}$ rajungan dalam berat $(\mathrm{kg})$ bubu kontrol terhadap bubu lampu putih, bubu kontrol terhadap bubu lampu biru dan bubu lampu putih terhadap lampu biru pada selang kepercayaan 95\% ( $>>0.05)$ dan hasil output uji T rajungan dalam jumlah (ekor) bubu kontrol terhadap bubu lampu putih, bubu kontrol terhadap bubu lampu biru dan bubu lampu putih terhadap bubu lampu biru pada selang kepercayaan 95\% ( $>0.05)$ adalah not significant.

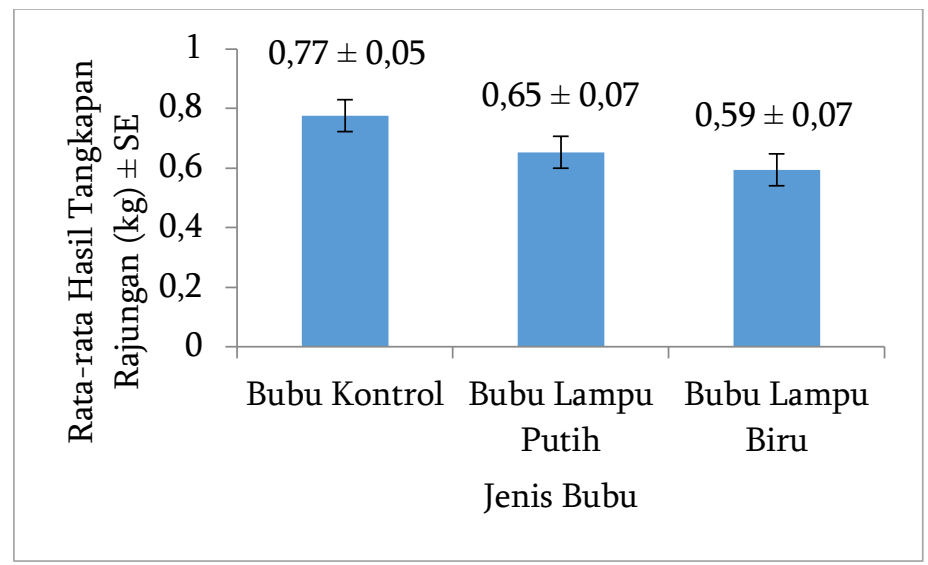

Gambar 7 Rata-rata hasil tangkapan rajungan dalam berat $(\mathrm{kg}) \pm \mathrm{SE}$ 


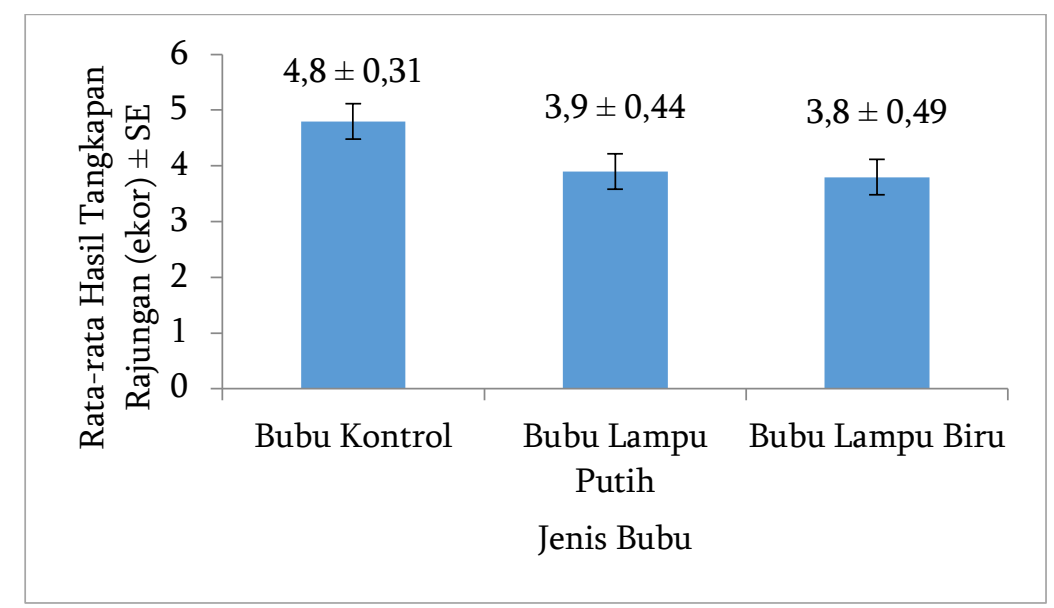

Gambar 8 Rata-rata hasil tangkapan rajungan dalam jumlah (ekor) $\pm \mathrm{SE}$

\section{Produktivitas Hasil Tangkapan}

Berdasarkan hasil tangkapan per trip yang dihitung berdasarkan berat $(\mathrm{kg})$ pada setiap bubu maka dapat diketahui produktivitas. Hasil perhitungan dapat dilihat pada Tabel 4.

Tabel 4 Produktivitas hasil tangkapan rajungan pada semua jenis bubu percobaan

\begin{tabular}{lccc}
\hline \multicolumn{1}{c}{ Jenis Bubu } & $\begin{array}{c}\text { Rajungan } \\
(\mathrm{kg} / \text { trip/bubu })\end{array}$ & $\begin{array}{c}\text { LEP } \\
(\mathrm{kg} / \text { trip/bubu })\end{array}$ & Total \\
\hline Bubu Kontrol & 0,077 & 0,089 & 0,166 \\
Bubu Modifikasi Lampu Putih & 0,065 & 0,122 & 0,187 \\
Bubu Modifikasi Lampu Biru & 0,059 & 0,080 & 0,139 \\
\hline
\end{tabular}

Berdasarkan Tabel 4 dapat disimpulkan bahwa bubu kontrol memiliki nilai produktivitas yaitu $0,166 \mathrm{~kg} /$ trip/bubu, bubu modifikasi lampu putih memiliki nilai produktivitas tertinggi yaitu 0.187 $\mathrm{kg} /$ trip/bubu, sedangkan bubu modifikasi lampu biru memiliki nilai produktivitas terendah yaitu 0,139 $\mathrm{kg} /$ trip/bubu.

Berdasarkan data penyebaran iluminasi cahaya baik warna biru maupun warna putih dapat dilihat terjadinya penurunan nilai iluminasi cahaya secara keseluruhan seiring dengan bertambahnya jarak titik percobaan terhadap sumber cahaya, hal ini dikarenakan pengukuran dilakukan pada media air laut sebagaimana diketahui air laut memiliki daya serap cahaya (Lisdawati et al. 2018) dan adanya aktivitas pembiasan oleh partikel pada air laut (Loupatty 2012). Pola sebaran cahaya pada pada Gambar 8 dan Gambar 9 menunjukan penyebaran cahaya sampai pada titik percobaan terjauh yaitu $50 \times 50 \mathrm{~cm}$, dapat diartikan bubu lipat modifikasi satu pintu yang secara dimensi memiliki tinggi $30 \mathrm{~cm}$, lebar 45 $\mathrm{cm}$, dan panjang $50 \mathrm{~cm}$ diterangi secara keseluruhan oleh lampu LED. Sehingga memungkinkan ikanikan yang berada pada jarak jangkau cahaya, baik secara vertikal maupun horizontal akan terpikat dan datang mendekati atau menuju arah datangnya cahaya tersebut.

Penggunaan lampu LED sebagai atraktor menyebabkan ikan yang tertangkap memiliki keragaman baik dari jenis dan ukuran, sesuai dengan pernyataan (Sudirman dan Mallawa 2004) dalam (Ammari 2013) bahwa kemampuan ikan tertarik pada suatu sumber cahaya sangat bervariasi, ada yang tertarik dengan intensitas cahaya rendah, ada yang tertarik dengan intensitas cahaya tinggi, dan ada pula yang tertarik dengan sumber cahaya tanpa peduli tingkat intensitas cahayanya. Dilihat dari jumlah ekor yang tertangkap pada ketiga bubu memiliki total yaitu 250 ekor maka rajungan (Portunus pelagicus) merupakan hasil tangkapan yang mendominasi. Berdasarkan wawancara dengan nelayan bahwa ketika penelitian dilakukan yaitu pada bulan Januari-Februari bertepatan dengan musim puncak rajungan (Portunus pelagicus) untuk daerah Kabupaten Pemalang khususnya Desa Jrakah. 
Berdasarkan hasil wawancara dengan pedagang ikan setempat bahwa alasan kepiting (Scylla sp) tidak termasuk kedalam hasil tangkapan bernilai ekonomis karena jenis kepiting (Scylla sp) yang tertangkap adalah kepiting lumpur yang berukuran kecil sehingga tidak diperdagangkan di tempat pelelangan ikan maupun pasar ikan. Penggunaan lampu LED sebagai atraktor menyebabkan ikan yang tertangkap memiliki keragaman baik dari jenis dan ukuran, sesuai dengan pernyataan (Sudirman dan Mallawa 2004) dalam (Ammari 2013) bahwa kemampuan ikan tertarik pada suatu sumber cahaya sangat bervariasi, ada yang tertarik dengan intensitas cahaya rendah, ada yang tertarik dengan intensitas cahaya tinggi, dan ada pula yang tertarik dengan sumber cahaya tanpa peduli tingkat intensitas cahayanya. Data hasil tangkapan menunjukan hasil tangkapan rajungan bubu lipat nelayan (bubu kontrol) sebanyak 96 ekor dengan total berat $15,53 \mathrm{~kg}$, bubu lipat modifikasi lampu putih 78 ekor dengan berat total 13,07 kg, dan bubu lipat modifikasi lampu biru 76 ekor dengan berat total 11,89 kg. Beberapa faktor yang menyebabkan rajungan pada bubu lipat modifikasi lampu LED yang tertangkap lebih sedikit bila dibandingkan dengan bubu kontrol adalah durasi perendaman bubu (Utami 2019), belum terbentuknya pola aktivitas baru pada lingkungan rajungan terhadap perubahan bubu (Zulkarnain et al. 2019) dalam hal ini penambahan cahaya sebagai atraktor, dan sebagai tambahan menurut (Ammari 2013) pancaran warna yang kurang jelas disebabkan faktor lingkungan akan mempengaruhi penglihatan ikan dalam membedakan objek.

Pengolahan data mengindikasikan bahwa lampu putih merupakan warna lampu yang paling efektif untuk penangkapan ikan demersal, hal ini sesuai dengan penelitian sebelum nya seperti Yudha (2005), Gustaman et al. (2012), Ammari (2013), dan (Reppie 2016) tentang penangkapan ikan demersal menggunakan atraktor cahaya. Menurut Yudha (2005) hasil tangkapan pada bubu yang menggunakan atraktor cahaya lebih baik apabila dibandingkan dengan bubu tanpa atraktor terutama pada bubu yang dipasang lampu putih. Gustaman et al. (2012) dan Reppie (2016) juga mengungkapkan hal yang sama yaitu lampu putih lebih efektif digunakan untuk penangkapan ikan jika dibandingkan dengan lampu biru, kuning, dan merah. Sedangkan Ammari (2013) memiliki pendapat bahwa lampu yang memiliki intensitas cahaya lebih besar akan cenderung memiliki hasil tangkapan lebih banyak apabila dibandingkan dengan bubu tanpa pemikat cahaya.

Produktivitas perikanan tangkap adalah kemampuran memperoleh hasil tangkapan yang ditentukan berdasarkan jumlah trip dan alat tangkap (Rahim 2017). Faktor yang mempengaruhi nilai produktivitas adalah jumlah hasil tangkapan sampingan hal tersebut dapat terjadi karena adanya modifikasi konstruksi bubu (Utami 2019) dan (Manurung 2006) mengungkapkan bahwa nilai produktivitas dipengaruhi oleh daerah penangkapan ikan serta teknik pengoperasian alat tangkap. Berdasarkan hasil perhitungan, nilai produktivitas bubu modifikasi lampu putih $(0,187 \mathrm{~kg} / \mathrm{trip} / \mathrm{bubu})$ lebih besar dibandingkan bubu kontrol (0,166 kg/trip/bubu) dan bubu modifikasi lampu biru $(0,139$ $\mathrm{kg} / \mathrm{trip} / \mathrm{bubu}$ ).

\section{KESIMPULAN DAN SARAN}

1. Komposisi hasil tangkapan yang diperoleh pada bubu kontrol (bubu nelayan) 9 jenis dengan total 248 ekor seberat 23,39 kg, bubu modifikasi lampu putih mendapatkan 10 jenis dengan total 224 ekor seberat $25,94 \mathrm{~kg}$, bubu modifikasi lampu biru juga mendapatkan 10 jenis hasil tangkapan dengan total 167 ekor seberat $17,42 \mathrm{~kg}$.

2. Penggunaan lampu LED berwarna putih dan biru dinyatakan tidak berpengaruh nyata dalam hasil tangkapan rajungan baik dalam jumlah (ekor) maupun berat $(\mathrm{kg}$ ) namun penggunaan lampu LED berwarna putih dinyatakan berpengaruh nyata dalam hasil tangkapan bernilai ekonomis baik dilihat dari jumlah (ekor) dan berat $(\mathrm{kg}$ ) apabila dibandingkan dengan bubu kontrol dan bubu modifikasi lampu biru. 
3. Nilai produktivitas hasil tangkapan bubu modifikasi lampu putih sebesar $0,187 \mathrm{~kg} /$ trip/bubu lebih besar dibandingkan dengan bubu kontrol yaitu 0,166 kg/trip/bubu dan bubu modifikasi lampu biru $0,139 \mathrm{~kg} /$ trip $/ \mathrm{bubu}$.

4. Bubu kontrol mendapatkan hasil tangkapan yang layak tangkap sebagai berikut rajungan (Portunus pelagicus) 90\%, gurita (Octopus sp) 33\%, udang ronggeng (Harpiosquilla sp) 86\%, dan Kuniran (Upeneus moluccensis) 100\%. Adapun persentase layak tangkap bubu modifikasi lampu putih yaitu rajungan (Portunus pelagicus) 74\%, gurita (Octopus sp) 18\%, udang ronggeng (Harpiosquilla sp) $56 \%$, cumi (Loligo sp) 38\%, kuniran (Upeneus moluccensis) 22\%. Bubu modifikasi lampu biru mendapatkan persentase hasil tangkapan layak tangkap terdiri dari rajungan (Portunus pelagicus) 71\%, udang ronggeng (Harpiosquilla sp) 20\%, cumi (Loligo sp) 33\%.

\section{DAFTAR PUSTAKA}

Adam, Jaya I, \& Sondita M F. 2006. Model Numerik Difusi Populasi Rajungan di Perairan Selat Makassar. Jurnal Ilmu-ilmu Perairan dan Perikanan Indonesia, 13(2), 83-88.

Ammari JA. 2013. Pengaruh Intensitas Cahaya Lampu LED Berkedip Terhadap Hasil Tangkapan Ikan Karang dengan Bubu di Perairan Pulau Ternate. Aquatic Science \& Management. 1(1), 39-44.

Ashari HB, Wibawa MB, \& Persada F S. 2017. Analisis Deskriptif dan Tabulasi Silang pada Konsumen online shop di Instagram (Studi Kasus 6 Universitas di Kota Surabaya). Surabaya (ID) : Jurnal Sains dan Seni ITS. 6(1), 10.

Gustaman G, Fauziyah, \& Isnaini. 2012. Efektifitas Perbedaan Warna Cahaya Lampu Terhadap Hasil Tangkapan Bagan Tancap di Perairan Sungsang Sumatera Selatan. Maspari Journal. 4(1), 92-102.

Lisdawati, Ahmad WS, \& Siwi OL. 2018. Studi Biomassa Lamun (Enhalus acoroides L.) dan (Halodule pinifolia) Berdasarkan Kedalaman Air Laut di Pantai Desa Tanjung Tiram Sulawesi Tenggara. Biowallacea. 5(2), 861-870.

Loupatty G. 2012. Analisis Warna Cahaya Lampu Terhadap Hasil Tangkapan Ikan. Jurnal Barekeng. 6(1), 47- 49.

Nazir M. 2003. Metode Penelitian. Jakarta (ID): Ghalia Indonesia.

Manurung DN. 2006. Produktivitas Unit Penangkapan Ikan dan Gaya Tenggelam Rumpon Laut Dalam di Perairan Selatan Palabuhanratu Sukabumi [skripsi]. Bogor (ID). Institut Pertanian Bogor

Novita DR, Nirmala K, Supriyono E, \& Ardi I. 2019. Efektivitas Paparan Spektrum Cahaya Lampu Light Emitting Diode (LED) Terhadap Pertumbuhan dan Kualitas Warna Yuwana Ikan Badut, Amphiprion percula (Lacèpède, 1802). Jurnal Ikhtiologi Indonesia. 19(1), 127-141.

Rahim A. 2017. Determinan Produktivitas Tangkapan dengan Model Estimasi Data Panel Fixed Effect. Jurnal Scientific Pinisi. 3(2), 86-92.

Reppie E. 2010. Pengaruh Minyak Cumi Pada Umpan yang Berbeda Pada Bubu Dasar Terhadap Hasil Tangkapan Ikan Karang. Manado (ID): Jurnal Perikanan dan Kelautan Tropis. 6(3), 142-144.

Santoso S. 2001. SPSS Versi 10 : Mengolah Data Statistik Secara Profesional. Jakarta: PT Elex Media Komputindo

Sudirman \& Mallawa. 2004. Teknik Penangkapan Ikan. Rineka Cipta Jakarta.

Thahir MA \& Taufiq. 2019. Pembuatan Lampu LED Celup untuk Perikanan Bubu di Perairan Lhok Bubon Kabupaten Aceh Barat. Aceh (ID): Jurnal Perikanan Tropis. 6(1) ???.

Utami WD. 2019. Penggunaan Dua Pintu Pada Konstruksi Mulut Bubu Lipat Modifikasi [skripsi]. Bogor (ID): Institut Pertanian Bogor. 
Yudha I. 2005. Pengaruh Warna Pemikat Cahaya (Light Attractor) Berkedip Terhadap Jenis dan Jumlah Ikan Hasil Tangkapan Bubu Karang (Coral Trap) di Perairan Pulau Puhawang Lampung Selatan [skripsi]. Lampung (ID): Universitas Lampung.

Zulkarnain. 2012. Rancang Bangun Bubu Lipat Modifikasi dan Penggunaan Cacing Tanah (Lumbricus rubellus) Sebagai Umpan Alternatif untuk Penangkapan Spiny lobster [desertasi]. Bogor (ID): Institut Pertanian Bogor.

Zulkarnain, Wahju IR, Wahyudi T, Purwangka F, \& Yuwandana DP. 2019. Teknologi Bubu Lipat Modifikasi Satu Pintu pada Penangkapan Rajungan (Portunus sp). Bogor (ID): Albacore. 3(2), $155-16$. 